Pathological Liver-function Tests in Patients Treated with Oral Contraceptives. Survey of Literature on General Clinical Trials and Solitary Cases of Yaundice

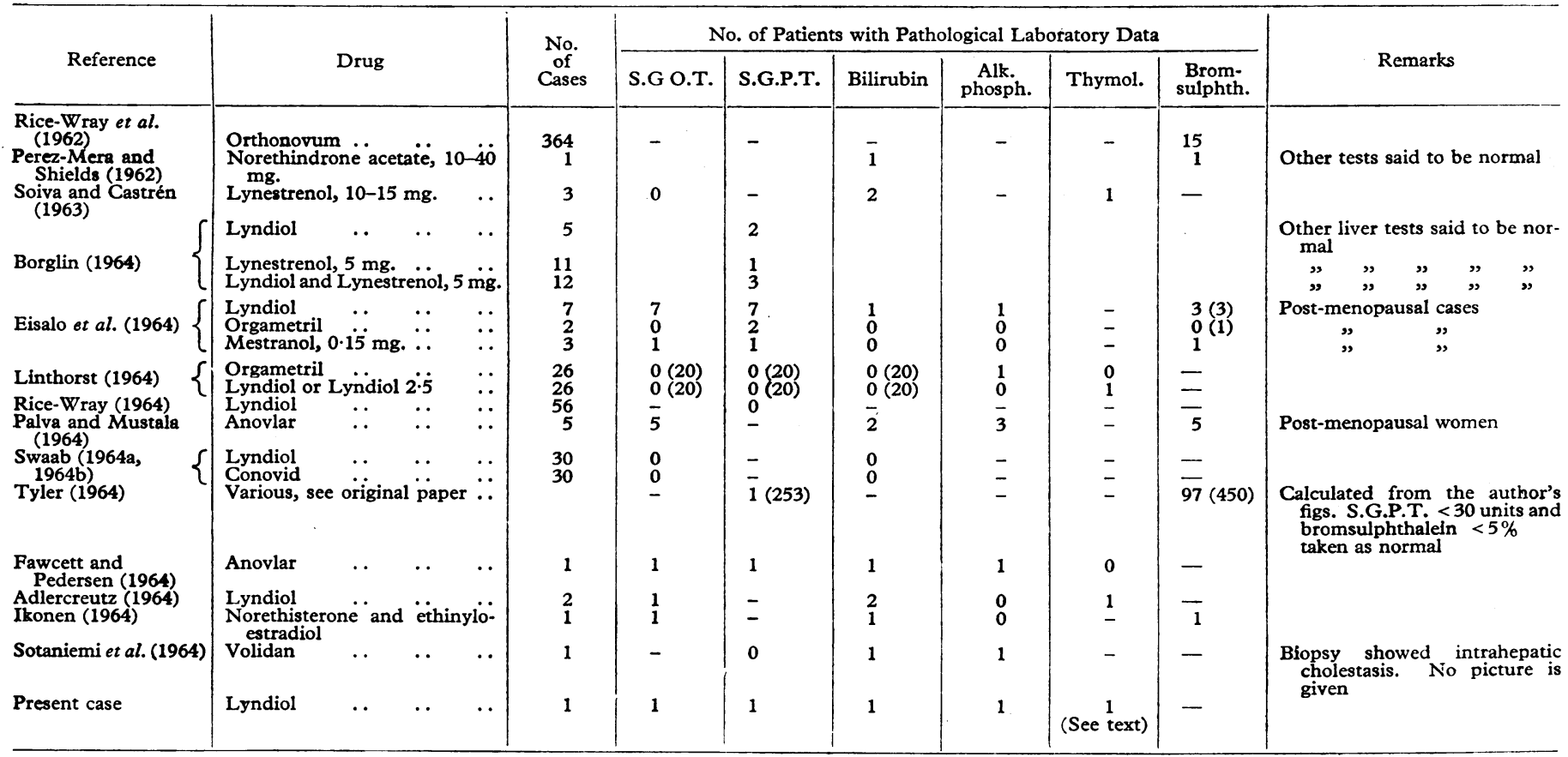

If all cases have not been tested, the number of tested cases is given within parentheses; - means not reported.

Pharmacological data : Orthonovum contains $0.06 \mathrm{mg}$. 3-methoxy ethinyloestradiol and $10 \mathrm{mg}$. norethindrone. Lyndiol contains $0.15 \mathrm{mg}$. mestranol and $5 \mathrm{mg}$. lynoestrenol. Lyndiol mite contains half the dose of Lyndiol (Lyndiol 2.5). Orgametril contains $5 \mathrm{mg}$. lynoestrenol. Anovlar contains $0.05 \mathrm{mg}$. ethinyloestradiol and 4 mg. norethisterone prescribed.

in Lyndiol-induced liver disease. Biopsy data during the icteric phase of Lyndiol jaundice seem to be restricted to the present case and that of Sotaniemi et al. (1964). Their biopsy is said to have shown intrahepatic cholestasis, but no picture is given. The experience with the thymol test is also limited.

It should be remembered in evaluating these data that in the present case and in the solitary cases at the end of the Table the relation between jaundice and drug is not unquestionable.

\section{Summary}

A case of jaundice which appeared during treatment with the oral contraceptive Lyndiol is reported. It is probable that the jaundice was caused by the drug. Laboratory data of the case include elevated levels of bilirubin, alkaline phosphatases, and transaminases. Biopsy of the liver showed intrahepatic cholestasis and hepatocellular damage. The case is compared with similar cases in the literature.

\section{REFERENCES}

Adlercreutz, H. (1964). Nord. Med., 72, 1004.

Borglin, N. (1964). Int. J. Fert., 9, 17.

Drill, v. A. (1963). Ann. N.Y.' Acad. Sci., 104, 858.

Eisalo, A., Järvinen, P. A., and Lunkkainen, T. (1964). Brit. med. 7., 2, 426.

Fawcett, J. W., and Perersen, D. L. (1964). Ibid., 2, 755.

Hall, M. J. (1960). Amer. J. clin. Path., 34, 313.

Ikonen, E. (1964). Acta obstet. gynec. scand., 43, Suppl. Na. 5.

Lancet, 1962, 1, 1056 .

Linthorst, G. (1964). Brit. med. 7., 2, 920.

Palva, I. P., and Mustala, O. O. (1964). Ibid., 2, 688.

Perez-Mera, R. A., and Shields, C. E. (1962). New Engl. ₹. Med., 267, 1137.

Rice-Wray, E. (1964). Brit. med. 7., 2, 1011

Rice-Wray, E. (1964). Brit. med. F., 2, 1011. 7. Amer. med. Ass., 180, 355 .

Smetana, H. F. (1963). Ann. N.Y. Acad. Sci., 104, 821.

Soiva, K., and Castrén, O. (1963). Ann. Chir. Gynaec. Fenn., 52, 376. Sotaniemi, E., Kreus, K. E., and Scheinin, T. M. (1964). Brit. med. F., 2, 1264 .

Swaab, L. (1964a). Int. F. Fert., 9, 107.

Tylo4b). Brit. med. 7., 2, 755 .

Zimmerman, H. J. (1963). Ann. N.Y. Acad. Sci., 104, 954.

\title{
Erythropoietin in Concentrates of Urine From Healthy Persons
}

\author{
PER HAAVARDSHOLM FINNE,* M.D.
}

\section{Brit. med. F., 1965, 1, 697-699}

The existence of a humoral factor (erythropoietin) controlling erythropoiesis is well established. There have, however, been some difficulties in demonstrating erythropoietin in blood from moderately anaemic or non-anaemic persons. A dual mechanism of erythropoietic regulation has therefore been suggested (Stohlman, 1959; Borsook et al., 1962), one mechanism based on erythropoietin acting in severe anaemias, another under normal conditions. Not all investigators agree with this theory (Gurney et al., 1961). The difficulties in demonstrating a correlation between the plasma erythropoietin levels and the haemoglobin concentrations in moderately anaemic persons have also been thought by some investigators to be due to the crudeness of the erythropoietin assay methods used to-day (Van Dyke et al., 1961).

If erythropoietin is the only humoral factor regulating the rate of erythrocyte formation under physiological conditions it should be demonstrable also in normal persons. Because of * Children's Department, Paediatric Research Institute, Rikshospitalet,
Oslo, Norway. 
the difficulties in assaying the erythropoietin in normal plasma, a better approach would be to measure the amount of erythropoietin excreted in the urine, for example, during 24 hours. To our knowledge no one has so far been able to demonstrate erythropoietin in normal urine, though several investigators have reported erythropoietic activity in urine from anaemic subjects (Piliero et al., 1956 ; Van Dyke et al., 1961 ; Hammond et al., 1962 ; Finne, 1964). A kidney threshold for erythropoietin excretion has therefore been postulated (Hammond et al., 1962).

The purpose of the present paper is to report investigations carried out in order to answer the question: Is erythropoietin excreted in the urine in normal persons?

\section{Material and Methods}

In a pilot study urine from four healthy male persons was collected, frozen down immediately after voiding, and kept in a deep-freezer $\left(-20^{\circ}\right.$ C. $)$. The urine was thawed, dialysed against distilled water for 48 hours at $4^{\circ} \mathrm{C}$., and then freezedried. The yield from each urine sample was dissolved in saline $(12-14 \mathrm{ml}$.) and injected subcutaneously into mice in doses of $1 \mathrm{ml}$. on two consecutive days. The erythropoietin content was determined by the use of the 72 -hour ${ }^{59} \mathrm{Fe}$ erythrocyte uptake in transfusion-induced polycythaemic mice (Rosse et al., 1962). As these concentrates showed significant erythropoietic activity (Table I), the 24-hour urine samples from four other healthy male persons were collected and concentrated in the same way as described above. This time, however, the yield from each sample was dissolved in $10 \mathrm{ml}$. of saline and injected into five mice in each group, $1 \mathrm{ml}$. on two consecutive days.

Amniotic fluid from normal pregnancies $(600 \mathrm{ml}$.) was also dialysed and freeze-dried in the same way as described for the urine. The yield after freeze-drying was dissolved in saline and injected into seven mice in doses of $1 \mathrm{ml}$. on two consecutive days. Unconcentrated urine and amniotic fluid was injected in doses of $1 \mathrm{ml}$. on two consecutive days.

Erythropoietin, standard B (from the National Institute for Medical Research, London, England), was injected in doses of 0.25 and 0.5 unit on two consecutive days into each mouse, in two groups, to show the sensitivity of the assay method, and to give an idea of the amount of erythropoietin excreted in the urine.

Control mice were injected with saline.

A well-type scintillation counter (Frieseke and Hoepfner, Erlangen-Bruch, Germany) was used for counting.

\section{Results}

Table I shows the percentage ${ }^{59} \mathrm{Fe}$ erythrocyte incorporation in mice injected with a concentrate of normal urine. Haemoglobin and red-cell values in the urine donors are also listed, and so are the urine volumes.

TABLE I.-Percentage ${ }^{59} \mathrm{Fe}$ Incorporation in Polycythaemic Mice Injected Subcutaneously with Concentrates of Urine from Four Healthy Male Persons. Urine Volumes and Haemoglobin and Red-cell Values of Urine Donors Are Also Given

\begin{tabular}{|c|c|c|c|c|c|}
\hline \multicolumn{4}{|c|}{ Urine Donors } & \multicolumn{2}{|c|}{ Recipient Mice } \\
\hline Donor & $\begin{array}{l}\mathrm{Hb} \\
\text { (g.) }\end{array}$ & $\begin{array}{l}\text { Red Cells } \\
\text { (mil./c.mm.) }\end{array}$ & $\begin{array}{c}\text { Urine } \\
\text { Volumes }\end{array}$ & $\begin{array}{c}{ }^{50} \mathrm{Fe} \text { Uptake } \\
\% \pm \text { s.e. }\end{array}$ & $\begin{array}{c}\text { Mean } \\
\text { Haematocrit } \\
\text { of Mice }\end{array}$ \\
\hline $\begin{array}{l}\mathrm{Aa} \\
\mathrm{Tr} \\
\mathrm{Ny} \\
\mathrm{Pf}\end{array}$ & $\begin{array}{l}16.3 \\
14.6 \\
14.8 \\
15.6\end{array}$ & $\begin{array}{l}5 \cdot 61 \\
5 \cdot 02 \\
4 \cdot 02 \\
4 \cdot 6\end{array}$ & $\begin{array}{r}900 \mathrm{ml} . \\
900 \mathrm{ml} \\
1,250 \mathrm{ml} . \\
880 \mathrm{ml}\end{array}$ & $\begin{array}{l}4 \cdot 1 \pm 2 \cdot 3(6) \\
2 \cdot 1 \pm 0.8(6) \\
7 \cdot 1 \pm 3 \cdot 2(7) \\
9 \cdot 3 \pm 4 \cdot 6(7)\end{array}$ & $\begin{array}{l}75 \\
74 \\
76 \\
80\end{array}$ \\
\hline
\end{tabular}

Figures in parentheses indicate number of recipient mice.

The first part of Table II shows the percentage ${ }^{59} \mathrm{Fe}$ erythrocyte incorporation in groups of mice injected with urine concentrates from 24-hour-urine samples from four healthy male persons. The number of red blood cells and the haemoglobin levels of the persons are also tabulated. All concentrates contained significant erythropoiesis-stimulating activity. Then the erythropoietic activity of amniotic fluid concentrated from $600 \mathrm{ml}$. is given. Finally, the sensitivity of the assay method is shown by injecting different doses of erythropoietin, standard B; mice injected with saline served as controls.

\section{Discussion}

The presented data clearly show that concentrates of normal urine have erythropoiesis-stimulating activity. Since it is generally upheld that erythropoietin is the only factor which initiates erythropoiesis in the polycythaemic mouse, it may be concluded that the erythropoiesis-stimulating factor in the urine concentrates is erythropoietin. The most reasonable interpretation of this is that erythropoiesis is also regulated through erythropoietin under physiological conditions. However, the chemical formula of the erythropoietic factor demonstrated in the normal urine is not proved to be the same as in anaemic persons, since the formula of erythropoetin is unknown.

The data also seem to indicate that there is no renal threshold for erythropoietin excretion, or that this threshold is so low that erythropoietin is excreted also under normal conditions.

It may be postulated that assaying the amount of erythropoietin excreted in the urine during a certain period of time

TABLE II.-Percentage ${ }^{59} \mathrm{Fe}$ Incorporation in Polycythaemic Mice Injected Subcutaneously with Concentrates of Urine from Four Healthy Males Collected During 24 Hours. The 24-hour Urine Volumes are Shown, so also are the Yield after Concentration, the Haemoglobin and Red-cell Values in Urine Donors. The Radioiron Incorporation in Mice Injected with a Concentrate from Normal Amniotic Fluid, Different Amounts of Erythropoietin, Standard B, Unconcentrated Urine, Amniotic Fluid, and Saline is also Shown

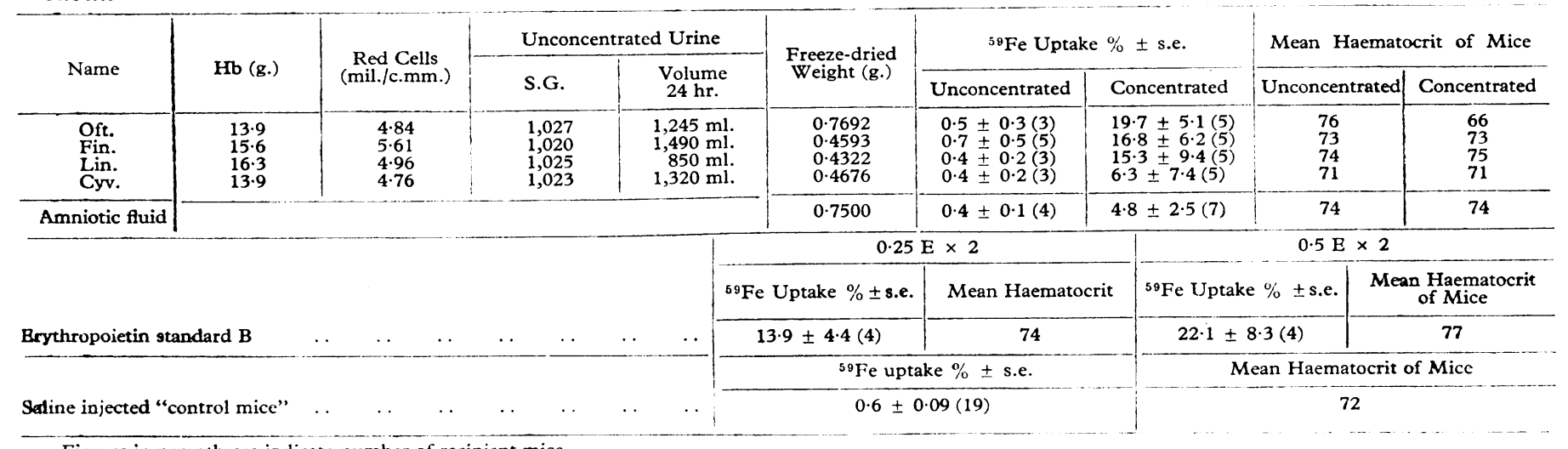


will give a better idea of the degree of humoral stimulation of erythropoiesis than measuring the plasma erythropoietin level.

When we want to compare from one laboratory to another the amount of erythropoietin found in the urine in different diseases, the method of concentration must be taken into consideration. The simple way of concentration by freezedrying after dialysis must be regarded as less destructive than precipitation or boiling. With these last methods a loss of erythropoietin may be suspected during the different procedures, although the end-product may be a more concentrated and pure one. However, so long as the only means of assaying the erythropoietin is by its biological activity and not by chemical quantitation, the easy way of concentration by dialysis and freeze-drying is most suitable for the purpose of quantitating urinary erythropoietin excretion.

As the amount of erythropoietin excreted under physiological conditions is as high as is shown in Table II, the discrimination between persons with different levels of erythropoietin excretion would be easier if the concentrates were divided in smaller doses than used in the present study-that is, injected into a greater number of mice-because the maximum response to erythropoietin is obtained with about 6-8 units per mouse (DeGowin et al., 1962). The contrary would be the case in persons with lowered erythropoietin excretion.

When measuring the amount of erythropoietin excreted in the urine the sensitivity of the assay method should be shown by a calibration curve using "standard erythropoietin." In this way the 24-hour erythropoietin excretion could be given in "standard units."

The demonstration of erythropoietin in normal amniotic fluid must be taken to be in favour of the hypothesis that erythropoiesis is regulated through erythropoietin antenatally as well. It is also likely that erythropoietin in the amniotic fluid is derived from the urine, since previous investigations have shown that in anaemic foetuses erythropoietin may be excreted in the urine (Finne, 1964).

\section{Summary}

Urine from normal healthy male persons has been concentrated by means of dialysis and freeze-drying. The yield has been dissolved in saline and injected into polycythaemic mice. The concentrated urine stimulates erythropoiesis - in the recipient mice and it is suggested that the effect may be due to erythropoietin. This strongly supports the hypothesis that erythropoietin is of physiological importance, not only in emergency situations but also under normal conditions as well. It is suggested that studying the 24-hour urinary excretion of erythropoietin may be a better way of estimating the erythropoietin production than assaying the plasma erythropoietin level.

A concentrate of normal amniotic fluid also showed erythropoiesis-stimulating activity. This favours the concept that erythropoiesis is regulated through erythropoietin antenatally as well as after birth.

I wish to acknowledge Nyegaard et Co. A/S for performing the freeze-drying. I also wish to thank Dr. D. R. Bangham, Director, Department of Biological Standards, National Institute for Medical Research, London, England, for generously placing erythropoietin standard B at my disposal.

\section{REFERENCES}

Borsook, H., Lingrel, J. B., Scaro, J. L., and Millette, R. L. (1962). Nature (Lond.), 196, 347.

DeGowin, R. L., Hofstra, D., and Gurney, C. W. (1962). Proc. Soc. exp. Biol. (N.Y.), 110, 48

Finne, P. H. (1964). Acta paediat. (Uppsala), 53, 269.

Gurney, C. W., Wackman, N., and Filmanowicz, E. (1961). Blood, 17, 531 .

Hammond, G. D., Ishikawa, A., and Keighley, G. (1962). Erythropoiesis, edited by L. O. Jacobson and M. Doyle. Grune \& Stratton, New York and London.

Piliero, S. J., Medici, P. T., Pansky, B., Luhby, A. L., and Gordon, A. S. (1956). Proc. Soc. exp. Biol. (N.Y.), 93, 302.

Rosse, W. W Waldmann, T. A., and Houston, D. E. (1962). Ibid., 109. 836.

Stohlman, F., jun. (1959). Ann. N.Y. Acad. Sci., 77, 710.

Van Dyke, D. C., Layrisse, M., Lawrence, J. H., Garcia, J. F., and Pollycove, M. (1961). Blood, 18, 187.

\section{Medical Memoranda}

\section{Serum Hepatitis Presenting as Sudden Loss of Consciousness}

Brit. med. F., 1965, 1, 699-700

While the occurrence of hepatitis following blood transfusion may be expected in $1 \%$ (Sherlock, 1963) to $3 \%$ (Allen and Sayman, 1962) of all recipients, and a proportion of these may develop hepatic failure, the presentation as sudden unconsciousness is uncommon enough to warrant recording.

\section{CASE History}

A gravida-2 aged 27 had a caesarean section on 16 December 1962 for concealed accidental haemorrhage, during the course of which she was transfused with 1 litre of compatible blood. She made an uneventful recovery apart from a urinary infection with Escherichia coli treated with nitrofurantoin.

Fourteen weeks later, at the end of March 1963, she began to feel unwell with anorexia and constipation, and on 29 March was noticed to be jaundiced. She was afebrile, and well enough to conduct her normal household duties.

On the evening of 31 March, while nursing her baby and feeling better than on the previous two days, she suddenly fell forward from her chair, dropping the child, and lay unconscious with her arms held rigid. She was admitted to the North Staffordshire Royal Infirmary one and a half hours later, when she was slightly restless but still unconscious, with no response to painful stimuli. $\mathrm{Her}$ temperature was $98.4^{\circ} \mathrm{F}$. $\left(36.9^{\circ} \mathrm{C}\right.$.), she was slightly icteric, and while her breath smelled of acetone no fetor hepaticus was detected. The spleen was impalpable and the liver appeared normal in size. She had no neck-stiffness, but both plantar responses were extensor. There were no other physical abnormalities, the blood-pressure being $130 / 70$.

The following investigations were carried out. Spinal fluid: Pressure $40 \mathrm{~mm}$. of spinal fluid; clear fluid containing 4 red cells and 3 white cells per c.mm.; protein $40 \mathrm{mg} . / 100 \mathrm{ml}$.; W.R. negative. Serum bilirubin $4.3 \mathrm{mg} . / 100 \mathrm{ml}$. Serum glutamic oxalo-acetic transaminase (S.G.O.T.) 235 units $/ 100 \mathrm{ml}$. Alkaline phosphatase 26.7 King-Armstrong units $/ 100 \mathrm{ml}$. Serum ure $22 \mathrm{mg} . / 100 \mathrm{ml}$. Serum albumin $5.7 \mathrm{~g} . / 100 \mathrm{ml}$. Serum globulin $2.2 \mathrm{~g} . / 100 \mathrm{ml}$. Haemoglobin $114 \%$ (16.8 g./100 ml.). White-cell count 7,100/c.mm. Blood sugar $100 \mathrm{mg} . / 100 \mathrm{ml}$. Prothrombin index $83 \%$ (method: Quick's one-stage). Urine contained bilirubin and increased urobilin. An electroencephalogram (E.E.G.) 36 hours 